\title{
A Review of Processes Behind Diversity-Productivity Relationships in Forests
}

\author{
David I. Forrester ${ }^{1} \cdot$ Jürgen Bauhus ${ }^{1}$
}

Published online: 3 February 2016

(C) Springer International Publishing AG 2016

\begin{abstract}
Through complementarity interactions, mixedspecies forests can be more productive than monocultures, and this effect can increase with tree-species richness. However, this is not always the case. This review examines the processes and stand structural attributes that can influence diversity-productivity relationships (DPRs); how they influence resource availability, resource uptake, and resource-use efficiency; and also describes some important differences between tree-diversity versus grassland-diversity experiments. The size of the complementarity effects caused by these processes and stand structures varies along spatial and temporal gradients in resource availability and climate. These spatial and temporal dynamics have now been examined in many studies, and the general patterns are summarized using a simple framework; complementarity is predicted to increase as the availability of resource " $X$ " declines (or climatic condition $X$ becomes harsher) if the species interactions improve the availability, uptake, or use efficiency of resource $X$ (or interactions improve climatic condition $X$ ). Importantly, this framework differs from the stress-gradient hypothesis to account for a wider range of inter-specific plant interactions (not only facilitation) by considering contrasting methods used to quantify species interactions while accounting for stand structure. In addition, complementarity (as opposed to facilitation)
\end{abstract}

This article is part of the Topical Collection on Ecological Function

David I. Forrester

david.forrester@waldbau.uni-freiburg.de

Jürgen Bauhus

juergen.bauhus@waldbau.uni-freiburg.de

1 Faculty of Environment and Natural Resources, Freiburg University, Tennenbacherstr. 4, Freiburg 79108, Germany for a given species combination can increase as growing conditions improve in forests, contrary to predictions of the stressgradient hypothesis with regards to facilitation. This review indicates that while the effects of tree-species diversity on growth and other forest functions are now receiving a lot of attention, far less is known about the effects of structural diversity on growth or forest functioning. Direct measurements of the processes, as opposed to focusing mainly on growth responses, could greatly contribute to our understanding of structural diversity effects.

Keywords Biodiversity $\cdot$ Complementarity $\cdot$ Facilitation . Production ecology equation $\cdot$ Stand structure

\section{Introduction}

Mixed-species stands can be more productive than monocultures. A global meta-analysis of studies comparing mixtures and monocultures found that mixed-species stands were on average $24 \%$ more productive than the mean of the monocultures of the given species combination, site, and age $[1 \bullet \cdot$. While many of the mixtures included in the meta-analysis contained only two species, numerous studies have shown that the productivity of forests can increase as the number of tree species increases (Fig. 1). These diversity-productivity relationships (DPRs) result from the growth dynamics of all species within the mixture and from their interactions.

To interpret Fig. 1, it is critical to consider that DPRs are also affected by stand density, resource availability, climatic conditions, stand age, disturbances, and whether species compositions are confounded with diversity levels; the species that are included at lower levels of diversity should be the same as those included at higher 


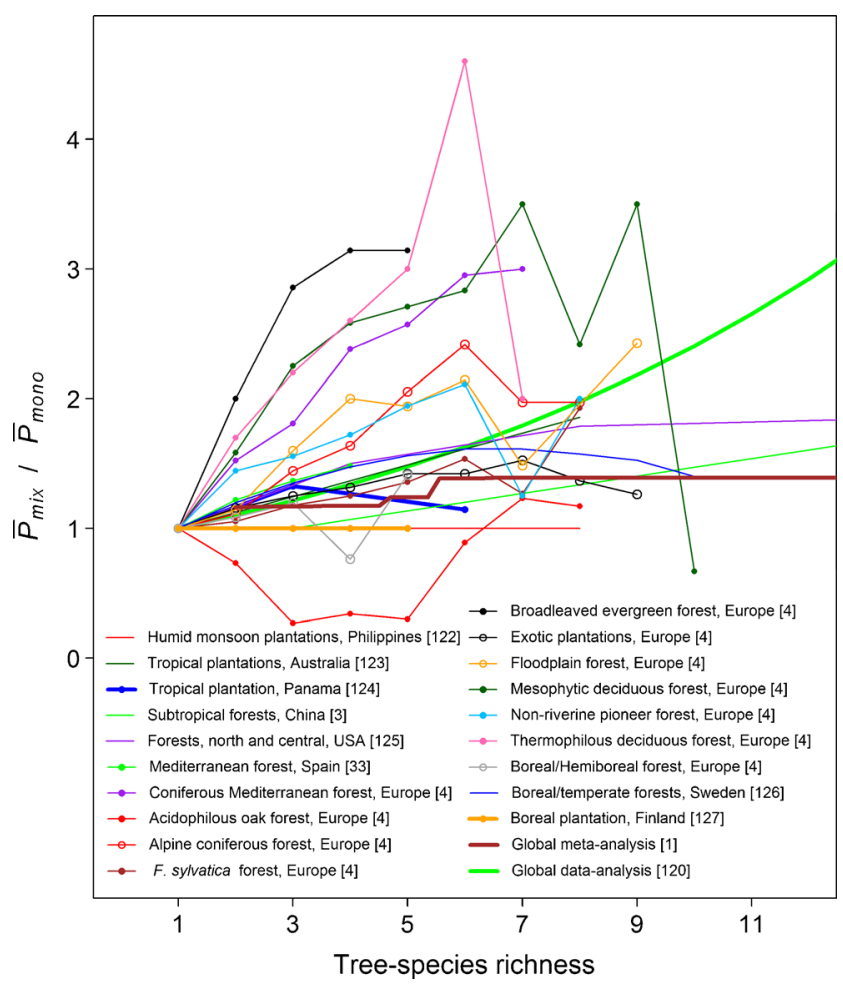

Fig. 1 Relationships between productivity and tree-species richness. Productivity was quantified as growth in terms of basal area, biomass, wood, or carbon mass. For a given study, the $y$ axis shows the mean productivity of a given richness level $\left(\bar{P}_{\text {mix }}\right)$ divided by the mean productivity of each monoculture in that study $\left(\bar{P}_{\text {mono }}\right)$ or the treatment with the lowest species richness if no monocultures were examined. For some studies, the "means" were calculated from regression lines. Studies that included standing stocks rather than growth were not included unless they were young plantations because standing stock is not necessarily correlated with productivity, particularly not at densities beyond canopy closure [121], and diversity-standing stock relationships can therefore be influenced by a different combination of factors compared with DPRs. The thick lines indicate the studies that accounted for factors that may have been confounded with species richness such as site characteristics, species pools, and stand density, either via the statistical analyses or because they were planted experiments. Note that while the $\bar{P}_{\text {mono }}$ is often lower than $\bar{P}_{\text {mix }}$, there may still have been monocultures that were more productive than the most productive mixtures

diversity levels to avoid sampling effects (Table 1). When the effects of these factors are separated from the diversity effects, the mechanisms driving the DPRs can become clearer and the slopes of the DPRs tend to be lower. For example, most of these factors were accounted for in the meta-analysis shown by the thick brown line in Fig. 1.

This review examines DPRs in forests, the processes, stand structures, and interactions that drive them and how they change along spatial and temporal gradients in resource availability or climatic conditions. Tree diversity is quantified differently in different studies. The most common is tree-species richness (number of tree species), followed by tree-species diversity, which is similar to tree species richness but also accounts for the evenness of the contribution of each species [2]. Other measures consider functional diversity and phylogenetic diversity; however, these are less commonly calculated, are harder to measure, and do not necessarily describe a higher proportion of the variation in productivity than tree-species richness or tree-species diversity $[3,4 \bullet]$; these latter ones will be used in this review.

While this review focuses on forests, it is important to acknowledge that DPRs in grassland communities have received a lot of attention, with a wide range of DPR slopes reported [5], consistent with the forest communities in Fig. 1. However, there are several important differences between tree-species communities and grassland communities that can make comparisons challenging, even when some of the processes, or the resulting patterns, are the same. For example, grassland studies often run for several lifetimes of many component species [6], whereas tree studies tend to run only for a (short) proportion of the potential life span of the trees. As a result, there are higher levels of mortality, recruitment (possibly also clonal reproduction), and species replacement during grassland community studies [6,7], thereby influencing species proportions, evenness, age structures, etc. This does not occur to the same extent in planted tree diversity experiments because many of the individuals present at the start are often still there after many years, it is unlikely or rare that species are lost from plots over short- to mediumterm periods, and no (or very few) new individuals will have been recruited into the canopy layer of the community $[8,9]$. This is an important distinction because in natural forests where recruitment was accounted for in the analyses, the positive DPRs resulted from higher recruitment in plots with higher tree-species diversity, as opposed to species interactions between, or faster growth of, the already established trees [10]. There can therefore be contrasting processes behind the temporal dynamics of grassland mixtures compared with tree mixtures where recruitment does not occur (or is accounted for in the analyses).

There are also large differences in the physiology and structure of trees compared with grasses and herbs. For example, the proportion of carbon partitioned to tissues used to capture and use resources (leaves and fine roots), as opposed to structural support tissues, was found to be approximately three times greater in grassland ecosystems compared with forest ecosystems in a global metaanalysis [11]. This has implications for many of the factors listed in Table 1, both in terms of the processes and the stand structural attributes. For example, within a single year, short-lived plants can replace nearly all aboveground structures, thereby rebuilding the whole canopy. In contrast, trees take much longer to develop their crowns and small differences in tree crown architectural 


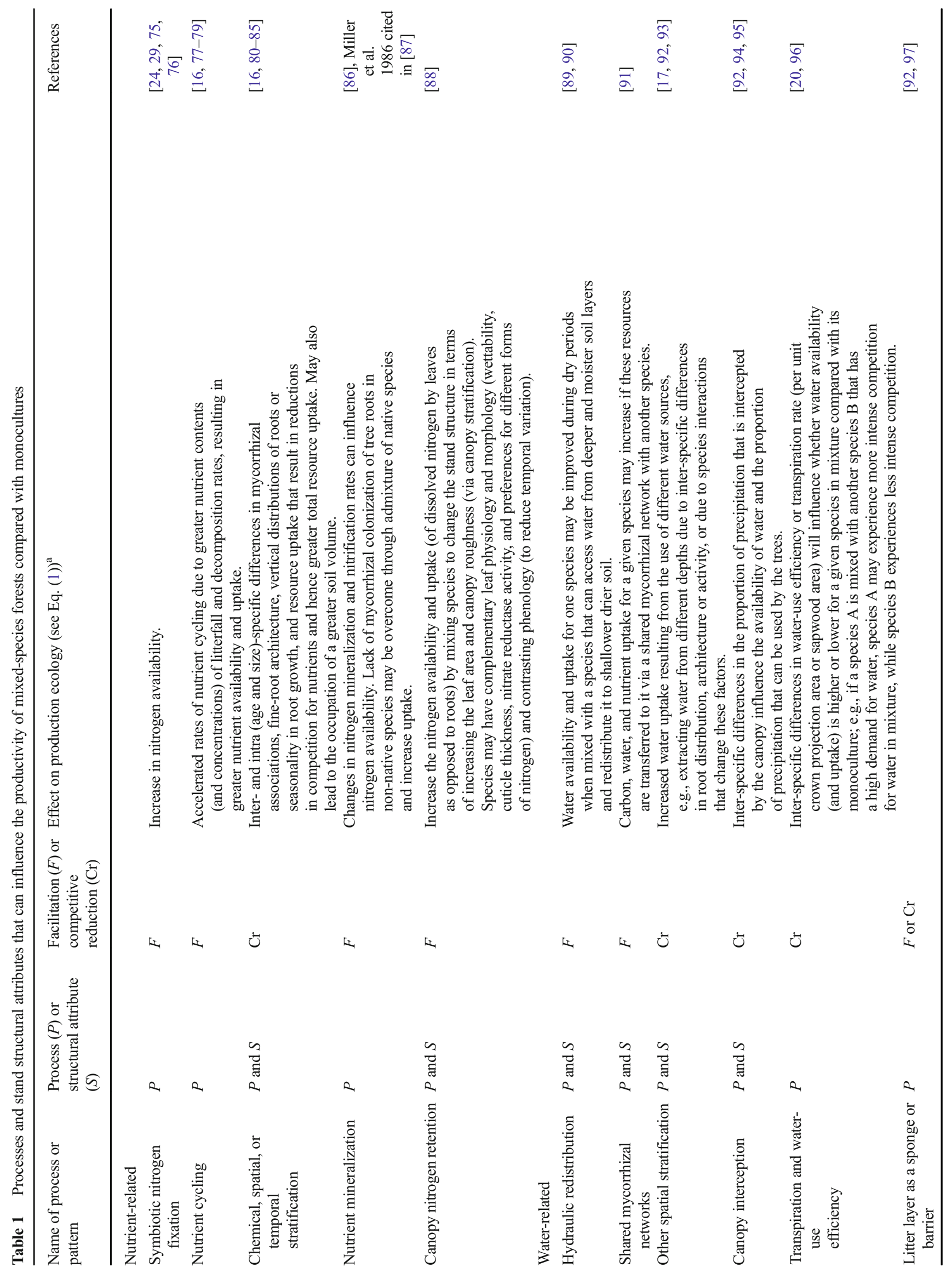




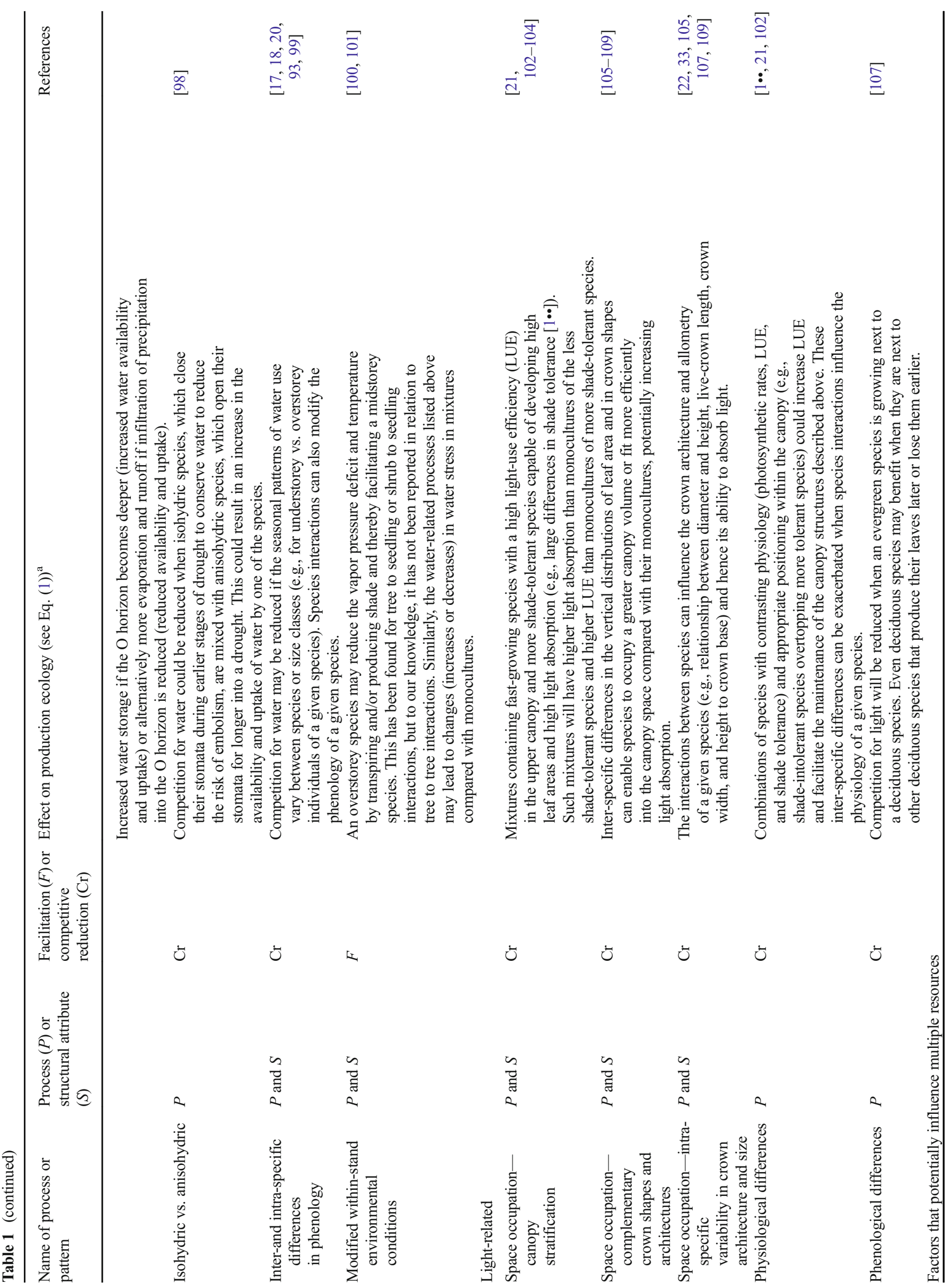




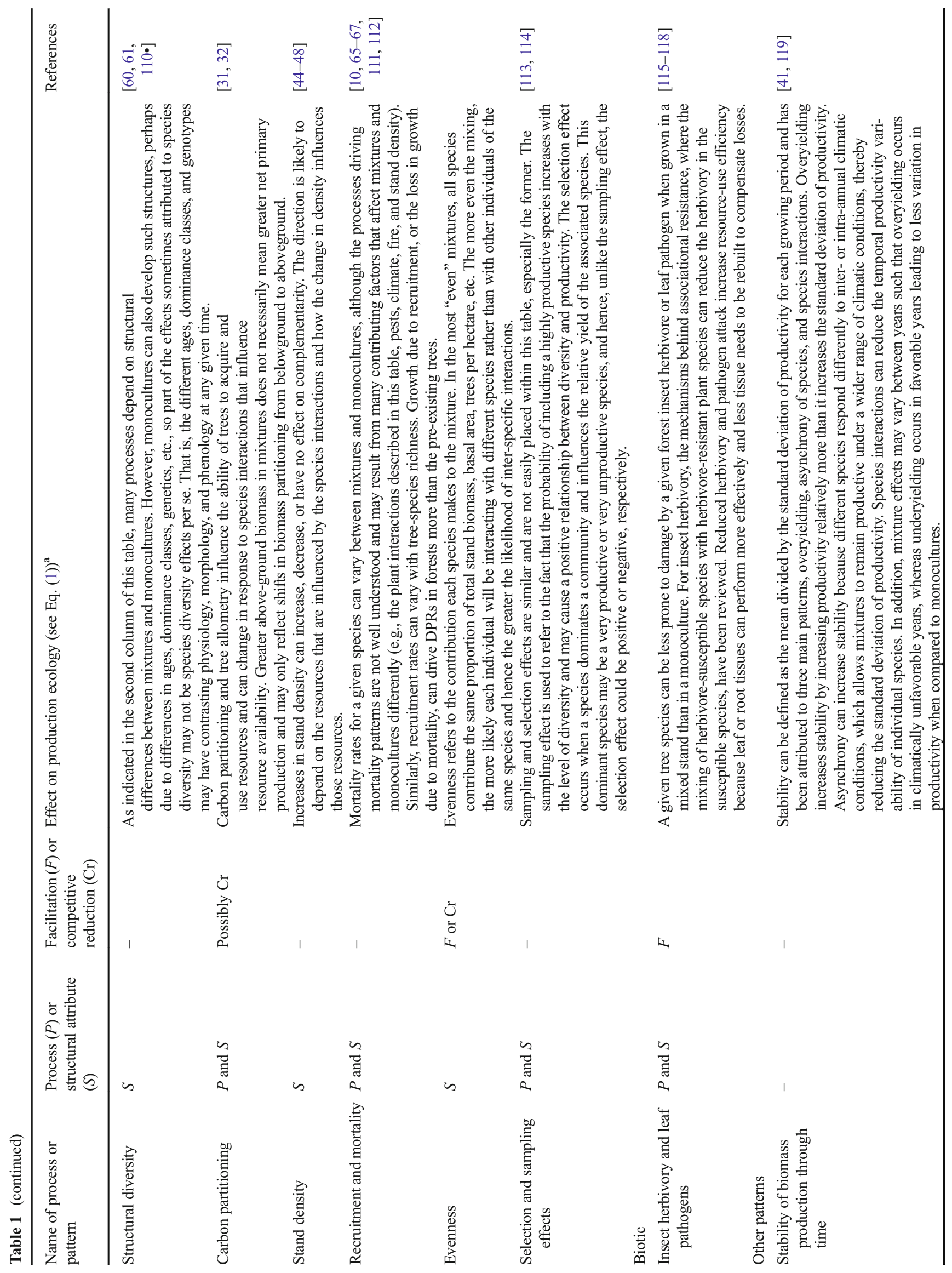




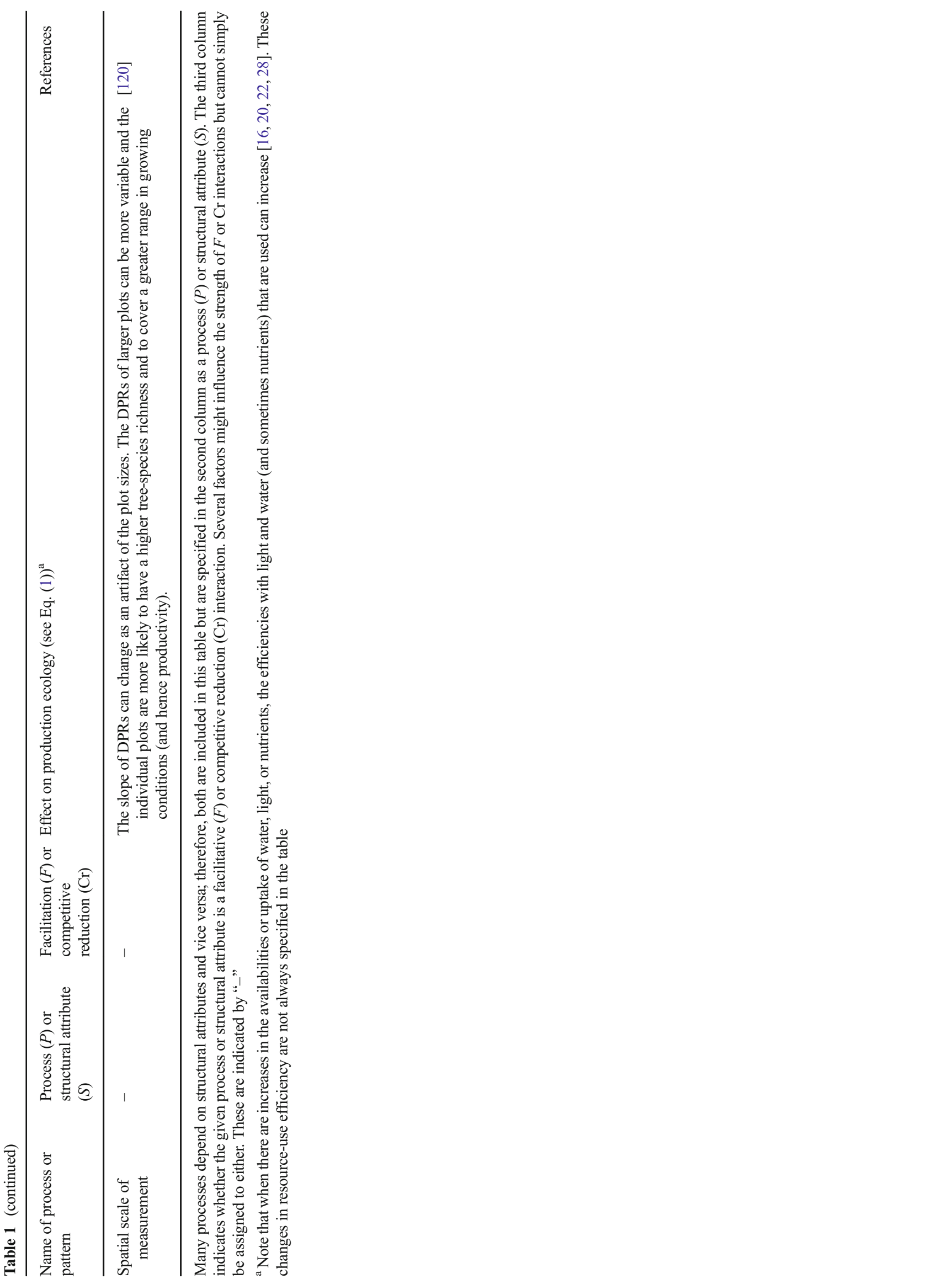


characteristics can accumulate year after year to have much larger effects as the stand canopy develops [7, 12]. This difference in the turnover rate of above-ground structures may also make forests less resilient than grasslands to disturbances [12].

In addition to these dynamics, the actual approaches used to quantify species mixing effects can vary between tree- and grassland-diversity experiments. For example, results presented for grassland experiments are often at the plot level and include means or totals for either a given species or the whole community. In contrast, it is relatively easy to examine the growth, resource capture, and resource use of individual trees or neighborhoods within a forest, and results are often also presented at the individual level in order to further understand the stand-level patterns, such as via allometric relationships, competition indices, and size distributions [13].

\section{Processes Influencing Diversity-Productivity Relationships}

The production ecology equation (Eq. (1) $[14,15])$ provides a framework to describe how different processes and species interactions can influence the growth of mixed-species forests.

Gross primary production $=$ resource supply

$\times$ fraction of resource acquired $\times$ resource use efficiency

For example, when the focus is on growth responses to light-related species interactions, above-ground biomass growth $\left(\mathrm{Mg} \mathrm{ha}^{-1}\right.$ year $\left.^{-1}\right)$ can be described using Eq. (1) as a function of the availability of photosynthetically active radiation (GJ ha ${ }^{-1}$ year $^{-1}$ ), the proportion of radiation that was absorbed (a fraction), and light-use efficiency ( $\mathrm{Mg}_{\text {biomass }}$ per GJ of absorbed radiation). Equation (1) has been used previously to examine the interactions in mixed-species stands in relation to nutrients [16], water [17-20], and light [21, 22].

Many processes can influence diversity-productivity relationships in forests (Table 1). They are generally based on inter-specific differences in physiology, phenology, or morphology or intra-specific differences that result from interspecific interactions. These processes are often grouped into those that represent competitive reduction or facilitation. Facilitation occurs when one species improves the resource availability, climatic or biotic conditions for another species, subsequently improving its growth or survival [23]. Examples of facilitative processes include symbiotic nitrogen fixation [24]; hydraulic lift [25]; and improved climatic conditions, e.g., prevention of frost [26]. In contrast, competitive reduction occurs when the intense intra-specific competition in monocultures is replaced by less intense inter-specific competition in mixtures [23]. Examples of competitive reduction processes include temporal, spatial, or chemical stratification within root systems and canopies that reduce competition for soil resources or light. Collectively, facilitation and competitive reduction are often referred to as complementarity.

The processes in Table 1 are not independent of each other. For example, increases in resource availability are likely to result in an increase in light- and water-use efficiencies [27, 28]. Increases in growth rates due to processes such as symbiotic nitrogen fixation may accelerate the development of stand structural diversity and hence influence processes related to structure (see column 2 in Table 1).

This inter-dependence also makes it difficult to separate the effects of facilitation and competitive reduction or even whether a given species is having a complementary or competitive effect on a single resource. For example, a given species can have different traits that simultaneously increase and decrease the availability of a given resource, e.g., for the resource water, low interception rates through pendulate leaves but high transpiration rates through dense fine-root systems. Therefore, just because a process is found to change in a mixture does not mean it has a significant net effect on growth because there may be opposing effects on the same resource or the process itself may simply be too weak to significantly influence growth. For example, growth often increases in mixtures containing nitrogen-fixing species, and this is often, at least partly, due to improved nitrogen availability and uptake, while a number of other interactions may also contribute [24]. However, sometimes there can be high rates of nitrogen fixation but no growth increase because nitrogen is not one of the most limiting resources at the site [29]. The production ecology equation and even more so, mass balance approaches, are useful tools to determine the contributions and importance of different processes [13, 30]. For example, a mass balance approach was used to determine whether greater above-ground productivity of mixtures was associated with greater total productivity or a shift in biomass partitioning between below-ground and above-ground biomass pools, or both. In some cases, the increase in above-ground production resulted only from a shift in partitioning, while in other cases, it was also associated with increased total productivity [31,32].

As indicated in Table 1, many complementarity processes have already been identified. Therefore, the following sections will focus on factors such as spatial or temporal gradients in resource availability or climatic conditions or stand structure that can also modify diversityproductivity relationships.

\section{Spatial and Temporal Dynamics}

The relative difference in productivity between monocultures and mixtures often increases with increasing tree-species richness (Fig. 1). The rate of increase typically declines as tree- 
(a)

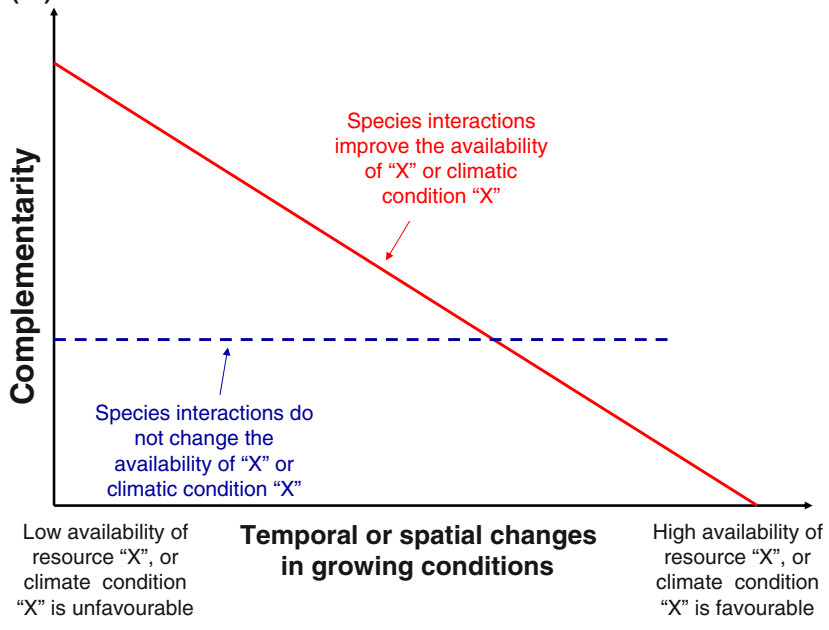

(b)

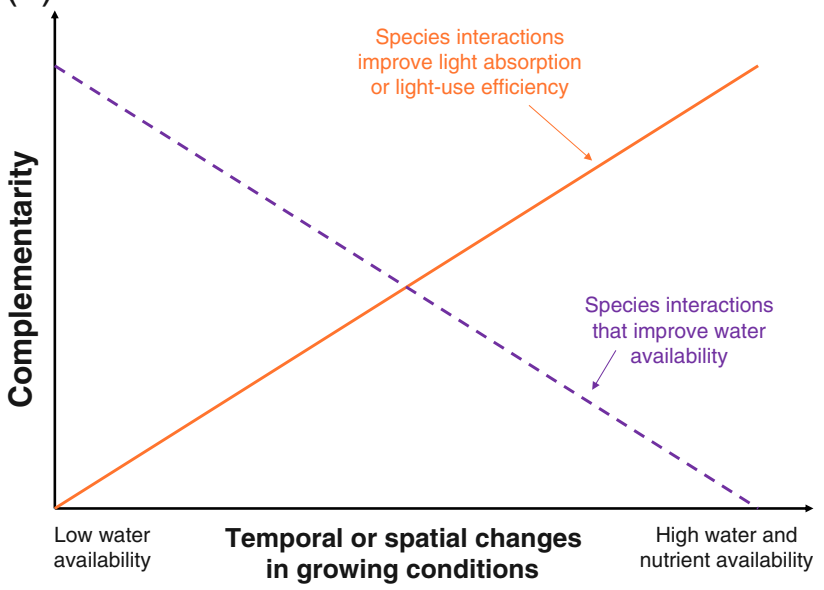

Fig. 2 A framework showing how the relative complementarity of given combinations of species change along temporal or spatial gradients in resource availability or climatic conditions. The solid red line in a shows a general pattern where complementarity increases as the availability of resource " $X$ " declines (or climatic condition $X$ becomes harsher) because the species interactions improve the availability, uptake, or use efficiency of resource $X$ (or interactions improve climatic condition $X$ ). For example, if $X$ is light, then complementarity might increase as light availability per tree declines (e.g., along a gradient of increasing stand leaf area index) and species interactions improve light absorption or light-use efficiency. The blue dashed line in $\mathbf{a}$ is a case where the species interactions do not lead to any change in complementarity along the gradient because complementarity does not result from interactions that influence $X$ or there is no complementarity for this species combination. Part b shows how different types of interactions could lead to

species richness increases. However, there is clearly considerable variability between the DPRs in Fig. 1 and the slope of these DPRs can change along spatial or temporal gradients in resource availability or climatic conditions, even for a given species pool. An understanding of these spatial and temporal dynamics is essential to predict when and where different types of processes (Table 1) are likely to lead to small versus large increases in ecosystem functions in mixtures compared with monocultures. contrasting complementarity patterns along a single gradient. The dashed purple line in $\mathbf{b}$ is an example of a community where the species interactions improve water availability, uptake, or use efficiency. These types of interactions result in larger complementarity effects as water becomes more limiting. The solid orange line in $\mathbf{b}$ is an example of a community where the species interactions improve light absorption or light-use efficiency and therefore complementarity increases with soil resource availability; as water and nutrient availabilities increase, stands can develop large leaf areas but competition for light will also increase, so any interactions that improve light absorption or use efficiency will become increasingly useful. Linear relationships are shown, but while many similar relationships reviewed by Forrester [34••] were approximately linear, there is currently not enough empirical information to determine what the shapes of these relationships might be. Modified from [45] and [34••]

It is important to note that we are referring to spatial and temporal changes in the DPR of a given species pool; the species at low levels of diversity are exactly the same as those at high levels of diversity. This reduces the possibility of a sampling or selection effect (Table 1). We are also focusing on studies without recruitment. In forests, growth due to recruitment can sometimes influence DPRs considerably more than the growth of the main (pre-existing) tree population [10], which may actually sometimes have a neutral DPR while 
the total stand (due to recruitment) has a positive or negative DPR. We therefore do not consider the effects of recruitment because it can result from many different types of disturbances and lead to many different factors listed in Table 1, pushing it beyond the scope of the simple framework described in this section.

\section{A Framework for Predicting Spatial and Temporal Changes in Complementarity}

We found no studies in forests with species pools of $>2$ species that examined spatial dynamics and only one that examined temporal dynamics. That study showed that the slope of a DPR in Iberian forests was higher during wet years and lower during dry years [33]. Many more studies have examined the spatial and temporal dynamics of species interactions in two-species mixtures. A review of these studies showed that the spatial and temporal changes in complementarity followed the simple pattern shown in Fig. 2 [34••]. When species interactions improve the availability, uptake, or use efficiency of a resource that is becoming more limiting along the spatial or temporal gradient, complementarity also tends to increase along that gradient (Fig. 2).

Figure $2 \mathrm{~b}$ indicates how the importance of water- and light-related interactions may change along a gradient. It is important to note that Fig. $2 \mathrm{~b}$ presents only an example of a specific case of the general framework shown in Fig. 2a. The pattern in Fig. $2 b$ does not mean to imply that water-related interactions cannot also be important on the same (moist) sites where light-related interactions are important $[34 \bullet \cdot]$. For example, on moist sites located at the right-hand side of the $x$ axis in Fig. 2b, there may be temporal changes in water availability due to droughts, such that during dry periods, water-related interactions become more important than during average conditions for that site. Similarly, as a stand develops over time, which may be located on a site anywhere along the $x$ axis, the competition for light, water, or nutrients may increase, thereby increasing the importance of these types of interactions as the stand develops; the opposite could also occur. Increases and decreases in complementarity with increasing age have been reported for tree mixtures, and when some of the processes in Table 1 were also measured, the patterns were consistent with the framework in Fig. $2[34 \bullet \bullet]$. Nevertheless, it is clear that this simple framework cannot simultaneously show all the different spatial or temporal gradients, or different processes, that are typically occurring in a single forest. The prediction of dynamics resulting from several simultaneously occurring processes can be achieved using process-based models that contain many of the processes or structural attributes listed in Table $1[35,36]$.
The Stress-Gradient Hypothesis as a Special Case Within the Conceptual Framework for Describing Complementarity in Forests

Many studies about mixed-species forests use the stressgradient hypothesis to interpret results. The framework in Fig. 2 is similar but also distinctly different to the stressgradient hypothesis, which suggests that facilitation will increase, and competition decrease, as conditions become harsher [37]. The stress-gradient hypothesis is a special case that fits within the framework in Fig. 2 but differs from it in three main ways. Firstly, the stress-gradient hypothesis deals with facilitation and not with competitive reduction interactions. The stress-gradient hypothesis therefore excludes many of the processes listed in Table 1, including all light-related processes as well as all water-/nutrient-related processes involving chemical, temporal, and spatial stratification.

Secondly, the quantification of facilitation itself usually differs in forest studies compared with those done under harsh environmental conditions where the stress-gradient hypothesis was developed [34••]. In stress-gradient hypothesis studies, facilitation is often quantified as the difference in growth, survival, or fitness of a plant growing with neighbors compared to a plant without neighbors. This no-neighbor situation is uncommon in forests, where facilitation and competitive reduction are often quantified as the difference in growth (or survival) of mixtures compared with monocultures. The stress-gradient hypothesis studies therefore confound species composition with stand density [34・•], which is a critical factor affecting forest growth and complementarity [4•], as explained below. Also, competitive reduction interactions cannot be quantified using a no-neighbor situation as a control, making it less common for the studies used to develop the stress-gradient hypothesis to consider competitive reduction interactions.

A third difficulty is that there are usually several simultaneously occurring processes driving the complementarity effects in mixed-species forests. Some may be facilitative, while others reduce competition. However, the contribution of each process to the total complementarity effect is very difficult to quantify and this is rarely attempted.

As a result of the three distinctions, described above, between stress-gradient hypothesis studies and forest studies, it is rare that forest studies fit the criteria on which the stressgradient hypothesis is based unless it is clear that facilitative processes (see Table 1) contributed most strongly to the complementarity effect or where the effects of facilitation can be separated from those of competitive reduction. However, we are not aware of any study in forests where facilitative interactions occurred in the absence of competitive reduction interactions or where the effects of facilitation had been separated from those of competitive reduction. The importance of the three distinctions described above is also illustrated by the fact 
that recent meta-analyses about the stress-gradient hypothesis do not include any studies about tree-tree interactions in forests [38, 39].

Despite these three distinctions between the studies used to develop the stress-gradient hypothesis compared with forest studies (and the framework in Fig. 2), several studies in forests have used the stress-gradient hypothesis to explain why complementarity increases as environmental conditions become harsher or along gradients of declining site productivity (e.g., [40, 41]). However, while the patterns in those studies were consistent with the stress-gradient hypothesis, a global meta-analysis found no consistent pattern $[1 \bullet \bullet]$, and contrary to the stress-gradient hypothesis, positive relationships between complementarity and growing conditions were found in about $25 \%$ of forest studies in a literature review [34••]. The framework in Fig. 2 predicts that complementarity can increase with resource availability or climatic conditions when the interactions between species improve light absorption or light-use efficiency. That is, as soil fertility or water availability increases, forests can develop larger leaf areas and so competition for light will probably increase. Therefore, any interactions that improve light absorption or light-use efficiency in the participating species could become increasingly important [22]. While the light-related interactions in Table 1 could also significantly increase light absorption in forests on infertile and dry sites, they are less likely to contribute to a positive DPR on such sites because growth is more limited by other resources. Figure 2 also explains why complementarity effects in many mixtures containing nitrogen-fixing species [24] were not correlated with site productivity or climatic conditions (as predicted by the stress-gradient hypothesis) and were instead related to soil nitrogen availability [34••].

This framework (Fig. 2) was developed by focusing on individual tree species within a mixture. We suggest that it is also applicable to the total community complementarity effect, the sum of all tree species within the stand. That is, while some species within a diverse mixture may grow faster than in their monoculture, other species may suffer and grow slower in the mixture; however, the total complementarity effect of all species within the given mixture is hypothesized to follow the same pattern as shown in Fig. 2.

\section{Stand Structure}

Many of the processes in Table 1 depend on differences in structures between mixtures and monocultures. Accounting for stand structure is critical when examining DPRs, when linking tree- and stand-level patterns, and is often an important consideration in experimental designs. There are many ways to define stand structure [42], and the processes in Table 1 could be divided into three broad aspects of stand structure, horizontal, vertical, and their variability in terms of structural diversity. Vertical structure is largely expressed in the stratification of crowns and root systems. Horizontal structure could be quantified as the horizontal variability in microsites [43], in terms of stand density, or as the evenness of mixing species (or age or size classes) in terms of species proportions or spatial arrangement that may be patterned fine (tree-bytree) intermediate (row-by-row or cluster-by-cluster) or coarse (group-by-group or patch-by-patch), where the spatial extent of a group or patch covers at least the crown projection areas of several mature trees of a given species.

\section{Stand Density}

Stand density, defined as the total number of trees per hectare, stand biomass, stand basal area, etc. can significantly affect DPRs. At very low densities, all interactions between trees will be weak, whether they are competitive or complementary. As density increases, so will the intensity of the interactions. Complementarity effects have been found to increase [44-46] and decrease [44, 47, 48], as stand density increases. The direction of the effect will depend on the resources (or climatic conditions) that are limiting growth and whether increasing density increases the strength of complementarity interactions for those resources more than it increases competition. Studies based on large inventory data sets have shown that stand density can be a stronger determinant of productivity than treespecies richness [4•, 49•]. All of these studies illustrate the importance of accounting for stand density when analyzing DPRs.

These studies also demonstrate different approaches to account for density. In planted tree diversity experiments, the initial density is controlled (same for each treatment) and the processes in Table 1 will then contribute to the development of inter-treatment differences in density; the different densities, and their effect on growth, become part of the treatment and may not need to be accounted for in analyses [13]. Therefore, these studies often compare treatments without adjusting for density (all plantation studies in Fig. 1). Alternatively, when density effects are of interest, neighborhood indices are used to separate the effects of density from the tree-species richness or tree-species identity effects (e.g., [13, 20, 44, 50, 51]). Both approaches are also used to analyze mixed-species plots established in existing forests, where initial density was not controlled and is not known. Here, differences in density may result from differences in age, soil/climatic conditions, previous management, disturbances, etc., and not species diversity. Therefore, in plots established in existing forest, it is important to ensure that the stand density of different diversity levels is the result of species interactions and not different management, stand disturbances, ages, and soil or climatic conditions [13]. Since quantitative information about previous management or natural disturbances is often unreliable or unavailable, most studies specifically focus on stands that are close to the maximum stand density and select at least one plot for each 
treatment at each site $[52,53]$. When this cannot be done, these factors have been accounted for by using structured equation models $[3,4 \bullet, 49 \bullet]$, multiple regression and grouping the data by site and density [54], and by analyzing tree-level patterns using neighborhood indices $[45,55,56]$.

\section{Evenness}

The importance of evenness has long been recognized and incorporated into experimental designs such as replacement series $[57,58]$. Generally, when there are complementarity effects, they are highest in the most evenly mixed treatments, e.g., the 1:1 treatments of two-species mixtures [24] or the treatments with the highest Shannon's index in more diverse plots $[1 \bullet \bullet]$. This occurs because the effects of processes listed in Table 1 are likely to be strongest, when each individual of a given species can directly interact with individuals of different species, rather than in distribution patterns where a high proportion of individuals of a given species interacts only with conspecific individuals rather than with those of a less common species, e.g., evenness in terms of spatial distributions. High evenness also indicates that even if the numbers of each species are similar, the contribution of biomass is also similar, as opposed to one or a few species dominating the others (e.g., [59]).

\section{Stand- or Neighborhood-Level Analysis of Stand Density and Evenness Effects}

Stand density and evenness are stand-level variables, but it is not necessary to examine their effects on DPRs using large "stand-level" plots, which requires a lot of time and money. Instead, they can be examined at the neighborhood level using neighborhood indices [13]. This makes use of the typical variability in the neighborhood of individual trees within a single forest plot in terms of stand density, species composition, and species proportions. Many studies have used neighborhood indices to examine and separate the effects of density, tree size, resource availability, and species proportions on productivity, resource uptake, or resource-use efficiency without the need for plot-level treatments/gradients in species diversity $[20,22,44,51,56]$. These neighborhood-level analyses will probably be valuable tools for future studies of DPRs because they also allow the analysis of older forest development phases, which are not yet represented by experiments. However, they will complement, not replace, stand-level approaches because those are required to examine stand-level patterns and processes or interactions with ecological disturbances that cannot be quantified by measurements at organ, tree or neighborhood levels.
Structural Diversity Can Increase and Decrease Productivity in Forests, Even in Monocultures

All of the processes in Table 1 that relate to structural attributes can, at least theoretically, also occur in monocultures. Indeed, structural diversity was positively correlated with forest productivity (Fig. 3) or above-ground biomass [60] in Canadian forests. Therefore, part of the diversity effects shown in Fig. 1 probably result from structural diversity rather than the species interactions and species diversity per se. From the framework of Fig. 2 and the production ecology equation, structural diversity will be most useful when it improves the capture or use efficiency of resources that are limiting. For example, structural diversity may be very valuable for processes related to microclimatic conditions, e.g., light absorption or $\mathrm{CO}_{2}$ uptake, but of less direct value in stands

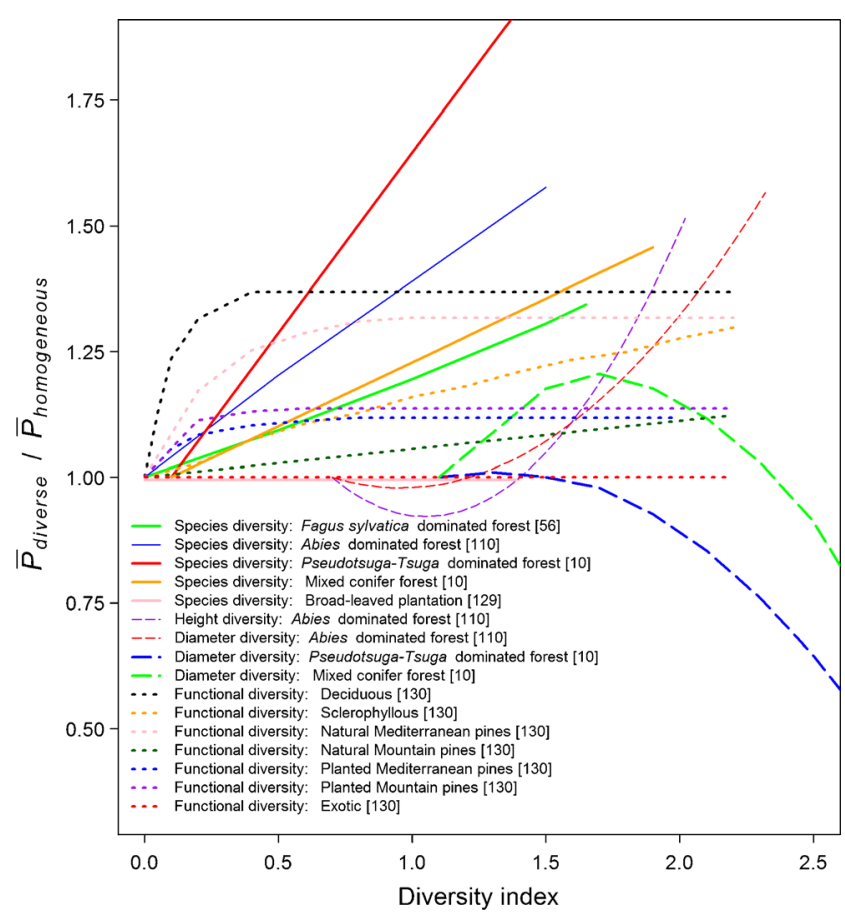

Fig. 3 Relationships between productivity and tree-species diversity, size diversity (in terms of tree diameters or tree heights), or functional diversity. Species and size diversity were calculated using Shannon's index [128], and functional diversity was calculated from the functional dispersion (a multidimensional index of functional diversity), which is the average distance of individual species from the centroid (center of mass) of all species, weighted by their relative abundance [130]. The productivity was quantified in terms of basal area increment, volume increment, or carbon increment. For a given study, the $y$ axis shows the mean productivity of a given diversity level $\left(\bar{P}_{\text {diverse }}\right)$ divided by the mean productivity of the least diverse stands in that study $\left(\bar{P}_{\text {homogeneous }}\right)$. For some studies, the "means" were calculated from regression lines. The thick lines indicate the studies that accounted for factors that may have been confounded with diversity such as site characteristics, species pools, and stand density, either via the statistical analyses or because they were planted experiments 
limited by resources less dependent on structure or where complementarity effects are dominated by processes that are less dependent on structure, such as nutrient cycling. Similarly, structural diversity can be calculated in different ways (e.g., using diameter versus height in Fig. 3 [61]), each of which is likely to vary in its representation of processes in Table 1 and may change as stands develop and their structures change.

However, this structural diversity effect is not straightforward because it can simultaneously have a negative effect on stand growth, at least in the absence of genetic diversity. These negative effects can be significant, e.g., $>10 \%$ reduction in stand growth $[62 \bullet \cdot, 63 \bullet, 64]$. To separate the effects of structural diversity from species and genetic diversity, fast-growing clonal eucalypt plantations were examined, where structural diversity was increased in a "heterogeneous" treatment by planting a third of the trees on day one, another third on day 40 , and the other third on day 80 . By age of 6 years, the wood biomass was $14 \%$ lower in the more structurally diverse stands. These absorbed a similar amount of light, but they were less light-use efficient than the more homogeneous stands [63•]. That is, in the structurally diverse stands, the benefit the dominant trees had in terms of greater light absorption and light-use efficiency was outweighed by a reduction in the light absorption and light-use efficiency of the suppressed trees. However, similar experiments have not been carried out with shade-tolerant tree species, where the effect of structure on light-use efficiency may differ from the above experiments with highly shade-intolerant species.

\section{Structural Diversity and Recruitment}

As noted above, the framework of Fig. 2 is based on forest and plantation studies without recruitment. The many potential processes and structures that lead to recruitment and the many potential effects that recruited tree cohorts could have on growth and other ecosystem functions are beyond the scope of this review. Nevertheless, recruitment and mortality will influence the structural diversity of a forest and can themselves be correlated with the structural and species diversities [10]. Very few studies have examined DPRs in forests with recruitment, or quantified the contribution of the recruited cohort, the original cohort, and mortality, to tree species or size diversity-productivity relationships in forests [10, 65-67].

\section{Quantifying the Effect of Structural Diversity on Forest Functioning}

Even in forests and planted experiments without any recruitment, the structural diversity of a stand is highly dynamic and its effects on productivity might be driven by several very different processes (Table 1) and therefore change in importance along spatial and temporal gradients in resource availability and climatic conditions (Fig. 2). These are very difficult to either monitor over long-stand developmental phases or to reconstruct (e.g., [68]). Therefore, we suggest that an efficient way forward is not to simply quantify and separate the effects of structural diversity and species diversity using indices (e.g., Shannon's index) and growth measurements but to combine this with a more process-based approach using the production ecology equation, the framework in Fig. 2, and by linking tree- and stand-level patterns.

\section{Next Steps}

Much information has now been gathered about how tree species interact in forests, how large the complementarity effects on growth can be, and how these effects can be quantified $[13,16,24,69,70]$. The dynamics of these complementarity effects along spatial and temporal gradients in resources and climate are less well understood [34.•] but are now receiving more attention because forest managers want to know where in the landscape, and in which phases of stand development, mixtures are beneficial. There are at least three main approaches that could be employed to develop this understanding and facilitate the transfer of information to practitioners. These include (1) experiments to provide empirical information under controlled conditions, (2) analyses of forest inventory data to provide regionally validated information across large spatial and temporal gradients, and (3) processbased models that link this knowledge and synthesize it into tools that can be used by forest managers.

A lot of attention has been given to the designs of planted experiments, and experiments established in existing forests, that provide detailed information about the processes in Table 1 while controlling for variation in resource availability, climate, stand density, age, species proportions, etc. [57, 58, 71-73]. In regards to measurements, the list of processes in Table 1 indicates the contribution that intra- and inter-specific differences in morphology, allometry, physiology, and phenology make to determine complementarity effects. While it should therefore be clear that it is necessary to take these differences into account when calculating complementarity effects or upscaling from the tree to the stand levels, they are sometimes ignored, such as when allometric or physiological information from monocultures is also applied to mixtures. This could strongly distort predictions of complementarity effects, resulting in misleading conclusions, and should be accounted for in future studies [13].

Carefully designed experiments are valuable sources of data, but they can be expensive and labour intensive to establish and maintain. These can be complemented with inventory data, which provide regionally validated information about complementarity effects with a broad spatial and long temporal resolution. These data need to be analyzed carefully to account for factors such as stand density $[13,74]$ and variation 
in soil resources and climatic conditions. For example, site indices are commonly used in forestry to summarize the effects of all climatic and soil resources that affect growth, but these are problematic when analyzing complementarity effects because they do not indicate which resources or climatic conditions change along the gradient. Yet, some of these resources determining growth may change in opposite directions with gradients in site indices, and it is these factors, not the site indices, that drive the complementarity effects [34••].

Experiments and inventory analyses are limited to the combinations of species, species proportions, site or climate characteristics, and management that were included in the data sets. However, there is often interest in the effects of different climatic conditions and novel combinations of species or management. Validated process-based forest growth models could be used to examine these scenarios [35, 36]. A recent review of forest growth models found that many could be used for mixed-species forests but very few have been validated by comparing their predictions of complementarity effects against measured complementarity effects [36].

\section{Conclusions}

Positive DPRs in forests are the result of many different types of species interactions. The importance of these different processes or interactions change as resource availability and climatic conditions change from site to site and as stands develop. Complementarity effects for a given species combination generally change along spatial or temporal gradients in resource availability or climate (Fig. 2), but these dynamics have not yet received much attention at richness levels of $>2$. Progress with understanding the spatial and temporal dynamics of DPRs is likely to be made using a process-based approach within the framework of the production ecology equation. These studies could be complemented with inventory data to obtain regionally validated information and also to develop process-based models that can be used to examine a much larger number of species compositions, site and climatic conditions, and silvicultural treatments and essentially to become management tools for foresters [35]. Finally, while many of the world's forests are mixed-species stands, the framework in Fig. 2 indicates that these are not always more productive than monocultures. It is worth noting that the fastest-growing stands in the world include very uniform, clonal Eucalyptus plantations with volume increments of $>80 \mathrm{~m}^{3} \mathrm{ha}^{-1}$ year $^{-1}$ [64], and these plantations are now specifically managed to be uniform to increase productivity. Species or structural diversities cannot increase the productivity of very efficient stands that are already at or near the physiological optimum and where a number of the benefits from mixed-species stands are addressed through management inputs such as fertilizers and control of weeds and pest species. It would be difficult to find species capable of competing with such trees in a mixture, and it is important to know when, where, and how this diversity is likely to be useful.

Acknowledgments D. Forrester was funded by a Heisenberg Fellowship (FO 791/4-1), and J. Bauhus received a research grant (BA 2821/14-3) from the German Research Foundation (Deutsche Forschungsgemeinschaft, DFG). We would like to thank the Section Editor, Kris Verheyen, for the invitation to write this review. We would also like to thank Kris Verheyen, Michael Scherer-Lorenzen, and two anonymous reviewers for their comments that helped to improve an earlier draft of this review.

\section{Compliance with Ethical Standards}

Conflict of Interest The authors declare no competing interests.

Human and Animal Rights and Informed Consent This article does not contain any studies with human or animal subjects performed by the author.

\section{References}

Papers of particular interest, published recently, have been highlighted as:

- Of importance

•. Of major importance

1.• Zhang Y, Chen HYH, Reich PB. Forest productivity increases with evenness, species richness and trait variation: a global meta-analysis. J Ecol. 2012;100:742-9. This paper is a global metaanalysis comparing mixtures and monocultures, which also identifies some important factors that influence the comparison.

2. Magurran AE. Measuring biological diversity. Malden: Blackwell; 2004.

3. Barrufol M, Schmid B, Bruelheide H, Chi X, Hector A, Ma K, et al. Biodiversity promotes tree growth during succession in subtropical forest. PLoS One. 2013;8:e81246.

4. Vilà M, Carrillo-Gavilán A, Vayreda J, Bugmann H, Fridman J, Grodzki W, et al. Disentangling biodiversity and climatic determinants of wood production. PLoS One. 2013;8(2):e53530. This study uses inventory data for 11 forest types and five European countries to show how productivity is influenced by richness while also accounting for stand density and climate.

5. Isbell F, Craven D, Connolly J, Loreau M, Schmid B, Beierkuhnlein $C$ et al. Biodiversity increases the resistance of ecosystem productivity to climate extremes. Nature. in press.

6. Niklaus PA, Leadley PW, Schmid B, Körner C. A long-term field study on biodiversity $\times$ elevated $\mathrm{CO}_{2}$ interactions in grassland. Ecol Monogr. 2001;71:341-56.

7. Körner C. An introduction to the functional diversity of temperate forest trees. In: Scherer-Lorenzen M, Körner C, Schulze E-D, editors. Forest diversity and function. Temperate and boreal systems. Ecological Studies 176. Berlin, Heidelberg, New York: Springer; 2005. p. 13-37. 
8. Potvin C, Dutilleul P. Neighborhood effects and size-asymmetric competition in a tree plantation varying in diversity. Ecology. 2009;90:321-7.

9. Mason WL. Long-term development of nursing mixtures of Sitka spruce and larch species in an experiment in northern Scotland. Forest Syst. 2014;23(3):590-7.

10. Liang J, Buongiorno J, Monserud RA, Kruger EL, Zhou M. Effects of diversity of tree species and size on forest basal area growth, recruitment, and mortality. For Ecol Manage. 2007;243: 116-27.

11. Poorter H, Niklas KJ, Reich PB, Oleksyn J, Poot P, Mommer L. Biomass allocation to leaves, stems and roots: meta-analyses of interspecific variation and environmental control. New Phytol. 2012;193:30-50.

12. Scherer-Lorenzen M, Körner C, Schulze E-D. The functional significance of forest diversity: a synthesis. In: Scherer-Lorenzen M, Körner C, Schulze E-D, editors. Forest diversity and function: temperate and boreal systems, Ecological Studies Volume 176. Heidelberg: Springer; 2005. p. 377-89.

13. Forrester DI, Pretzsch H. Tamm review: on the strength of evidence when comparing ecosystem functions of mixtures with monocultures. For Ecol Manage. 2015;356:41-53.

14. Monteith JL. Climate and the efficiency of crop production in Britain. Philos Trans R Soc Lond B. 1977;281:277-94.

15. Binkley D, Stape JL, Ryan MG. Thinking about efficiency of resource use in forests. For Ecol Manage. 2004;193:5-16.

16. Richards AE, Forrester DI, Bauhus J, Scherer-Lorenzen M. The influence of mixed tree plantations on the nutrition of individual species: a review. Tree Physiol. 2010;30:1192-208.

17. Forrester DI, Theiveyanathan S, Collopy JJ, Marcar NE. Enhanced water use efficiency in a mixed Eucalyptus globulus and Acacia mearnsii plantation. For Ecol Manage. 2010;259: 1761-70. doi:10.1016/j.foreco.2009.07.036.

18. Moore GW, Bond BJ, Jones JA. A comparison of annual transpiration and productivity in monoculture and mixed-species Douglas-fir and red alder stands. For Ecol Manage. 2011;262: 2263-70.

19. Kunert N, Schwendenmann L, Potvin C, Hölscher D. Tree diversity enhances tree transpiration in a Panamanian forest plantation. J Appl Ecol. 2012;49:135-44.

20. Forrester DI. Transpiration and water-use efficiency in mixedspecies forests versus monocultures: effects of tree size, stand density and season. Tree Physiol. 2015;35:289-304.

21. Binkley D, Dunkin KA, DeBell D, Ryan MG. Production and nutrient cycling in mixed plantations of Eucalyptus and Albizia in Hawaii. Forest Sci. 1992;38(2):393-408.

22. Forrester DI, Albrecht AT. Light absorption and light-use efficiency in mixtures of Abies alba and Picea abies along a productivity gradient. For Ecol Manage. 2014;328:94-102.

23. Vandermeer J. The ecology of intercropping. New York: Cambridge University Press; 1989.

24. Forrester DI, Bauhus J, Cowie AL, Vanclay JK. Mixed-species plantations of Eucalyptus with nitrogen fixing trees: a review. For Ecol Manage. 2006;233:211-30. doi:10.1016/j.foreco.2006.05.012.

25. Zapater M, Hossann C, Bréda N, Bréchet C, Bonal D, Granier A. Evidence of hydraulic lift in a young beech and oak mixed forest using ${ }^{18} \mathrm{O}$ soil water labelling. Trees. 2011;25:885-94.

26. Langvall O, Örlander G. Effects of pine shelterwoods on microclimate and frost damage to Norway spruce seedlings. Can J Forest Res. 2001;31:155-64.

27. Stape JL, Binkley D, Ryan MG. Eucalyptus production and the supply, use and efficiency of use of water, light and nitrogen across a geographic gradient in Brazil. For Ecol Manage. 2004;193:1731 .

28. Binkley D. Understanding the role resource use efficiency in determining the growth of trees and forests. In: Schlichter T, Montes
L, editors. Forests in development: a vital balance. Netherlands: Springer; 2012. p. 13-26.

29. Binkley D, Sollins P, Bell R, Sachs D, Myrold D. Biogeochemistry of adjacent conifer and alder-conifer stands. Ecology. 1992;73:2022-33.

30. Binkley D, Menyailo O. Gaining insights on the effects of tree species on soils. In: Binkley D, Menyailo O, editors. Tree species effects on soils: implications for global change. Dordrecht: NATO Science Seriews, Kluwer Academic Publishers; 2005. p. 1-16.

31. Forrester DI, Bauhus J, Cowie AL. Carbon allocation in a mixedspecies plantation of Eucalyptus globulus and Acacia mearnsii. For Ecol Manage. 2006;233:275-84. doi:10.1016/j.foreco.2006. 05.018 .

32. Epron D, Nouvellon Y, Mareschal L, MoreiraeMoreira R, Koutika L-S, Geneste B, et al. Partitioning of net primary production in Eucalyptus and Acacia stands and in mixed-species plantations: two case-studies in contrasting tropical environments. For Ecol Manage. 2013;301:102-11.

33. Jucker T, Bouriaud O, Avacaritei D, Dănilă I, Duduman G, Valladares F, et al. Competition for light and water play contrasting roles in driving diversity productivity relationships in Iberian forests. J Ecol. 2014;102:1202-13.

34.• Forrester DI. The spatial and temporal dynamics of species interactions in mixed-species forests: from pattern to process. For Ecol Manage. 2014;312:282-92. This paper provides the framework used for Figure 2 that describes the spatial and temporal dynamics of complementarity and also reviews the empirical forest studies that have examined these patterns.

35. Forrester DI, Tang X. Analysing the spatial and temporal dynamics of species interactions in mixed-species forests and the effects of stand density using the 3-PG model. Ecol Model. 2016;319: 233-54.

36. Pretzsch H, Forrester DI, Rötzer T. Representation of species mixing in forest growth models. A review and perspective. Ecol Model. 2015;313:276-92.

37. Bertness MD, Callaway RM. Positive interactions in communities. Trends Ecol Evol. 1994;9:191-3.

38. He Q, Bertness MD, Altieri AH. Global shifts towards positive species interactions with increasing environmental stress. Ecol Lett. 2013;16:695-706.

39. Soliveres S, Maestre FT. Plant-plant interactions, environmental gradients and plant diversity: a global synthesis of communitylevel studies. Perspect Plant Ecol Evol Syst. 2014;16:154-63.

40. Toïgo M, Vallet P, Perot T, Bontemps J-D, Piedallu C, Courbaud B. Overyielding in mixed forests decreases with site productivity. J Ecol. 2015;103:502-12.

41. Río M, Schütze G, Pretzsch H. Temporal variation of competition and facilitation in mixed species forests in central Europe. Plant Biol. 2014;16:166-76.

42. McElhinny C, Gibbons P, Brack C, Bauhus J. Forest and woodland stand structural complexity: its definition and measurement. Forest Ecol Manag. 2005;218(1-3):1-24.

43. Boyden S, Montgomery R, Reich PB, Palik B. Seeing the forest for the heterogeneous trees: stand-scale resource distributions emerge from tree-scale structure. Ecol Appl. 2012;22(5):1578-88.

44. Boyden S, Binkley D, Senock R. Competition and facilitation between Eucalyptus and nitrogen-fixing Falcataria in relation to soil fertility. Ecology. 2005;86(4):992-1001.

45. Forrester DI, Kohnle U, Albrecht AT, Bauhus J. Complementarity in mixed-species stands of Abies alba and Picea abies varies with climate, site quality and stand density. For Ecol Manage. 2013;304:233-42.

46. Condés S, Rio MD, Sterba H. Mixing effect on volume growth of Fagus sylvatica and Pinus sylvestris is modulated by stand density. For Ecol Manage. 2013;292:86-95. 
47. Garber SM, Maguire DA. Stand productivity and development in two mixed-species spacing trials in the Central Oregon Cascades. Forest Sci. 2004;50:92-105.

48. Río M, Sterba H. Comparing volume growth in pure and mixed stands of Pinus sylvestris and Quercus pyrenaica. Ann For Sci. 2009;66:502.

49. Paquette A, Messier C. The effect of biodiversity on tree productivity: from temperate to boreal forests. Glob Ecol Biogeogr. $2011 ; 20: 170-80$. This study uses inventory data from Canadian forests to show how productivity is influenced by richness while also accounting for stand density and climate.

50. Vanclay JK. Spatially-explicit competition indices and the analysis of mixed-species plantings with the Simile modelling environment. For Ecol Manage. 2006;233:295-302.

51. Forrester DI, Vanclay JK, Forrester RI. The balance between facilitation and competition in mixtures of Eucalyptus and Acacia changes as stands develop. Oecologia. 2011;166(1):265-72.

52. Pretzsch H, Block J, Dieler J, Dong PH, Kohnle U, Nagel J, et al. Comparison between the productivity of pure and mixed stands of Norway spruce and European beech along an ecological gradient. Ann For Sci. 2010;76:712-23.

53. Pretzsch H, del Río M, Ammer C, Avdagic A, Barbeito I, Bielak $\mathrm{K}$, et al. Growth and yield of mixed versus pure stands of Scots pine (Pinus sylvestris L.) and European beech (Fagus sylvatica L.) analysed along a productivity gradient through Europe. Eur J For Res. 2015;134:927-47.

54. Potter KM, Woodall CW. Does biodiversity make a difference? Relationships between species richness, evolutionary diversity, and aboveground live tree biomass across U.S. forests. For Ecol Manage. 2014;321:117-29.

55. von Oheimb G, Lang AC, Bruelheide H, Forrester DI, Wäsche I, $\mathrm{Yu} \mathrm{M}$, et al. Individual-tree radial growth in a species-rich subtropical forest: the role of local neighbourhood competition. Forest Ecol Manag. 2011;261:499-507. doi:10.1016/j.foreco.2010.10. 035 .

56. Ratcliffe S, Holzwarth F, Nadrowski K, Levick S, Wirth C. Tree neighbourhood matters - tree species composition drives diversity-productivity patterns in a near-natural beech forest. For Ecol Manage. 2015;335:225-34.

57. Vanclay JK. Experiment designs to evaluate inter- and intraspecific interactions in mixed plantings of forest trees. For Ecol Manage. 2006;233:366-74.

58. Kelty MJ, Cameron IR. Plot designs for the analysis of species interactions in mixed stands. Commonwealth Forestry Rev. 1995;74(4):322-32.

59. Bouillet J-P, Laclau J-P, Gonçalves JLM, Voigtlaender M, Gava JL, Leite FP, et al. Eucalyptus and Acacia tree growth over entire rotation in single- and mixed-species plantations across five sites in Brazil and Congo. For Ecol Manage. 2013;301:89-101.

60. Zhang Y, Chen HYH. Individual size inequality links forest diversity and above-ground biomass. J Ecol. 2015;103:1245-52.

61. Wang W, Lei X, Ma Z, Kneeshaw DD, Peng C. Positive relationship between aboveground carbon stocks and structural diversity in spruce-dominated forest stands in New Brunswick. Can Forest Sci. 2011;57:506-15.

62.• Binkley D, Stape JL, Bauerle WL, Ryan MG. Explaining growth of individual trees: Light interception and efficiency of light use by Eucalyptus at four sites in Brazil. For Ecol Manage. 2010;259: 1704-13. This paper shows how structural diversity can have a negative effect on productivity.

63. Ryan MG, Stape JL, Binkley D, Fonseca S, Loos RA, Takahashi EN, et al. Factors controlling Eucalyptus productivity: how water availability and stand structure alter production and carbon allocation. Forest Ecol Manag. 2010;259:1695-703. This paper quantifies the negative effect that structural diversity can have on stand productivity.
64. Stape JL, Binkley D, Ryan MG, Fonseca S, Loos RA, Takahashi EN, et al. The Brazil Eucalyptus potential productivity project: influence of water, nutrients and stand uniformity on wood production. Forest Ecol Manag. 2010;259:1684-94.

65. Liang J, Buongiorno J, Monserud RA. Growth and yield of allaged Douglas-fir-western hemlock forest stands: a matrix model with stand diversity effects. Can J Forest Res. 2005;35:2368-81.

66. Lasky JR, Uriarte M, Boukili VK, Erickson DL, Kress WJ, Chazdon RL. The relationship between tree biodiversity and biomass dynamics changes with tropical forest succession. Ecol Lett. 2014; 17:1158-67.

67. Young B, Liang J, Chapin FS. Effects of species and tree size diversity on recruitment in the Alaskan boreal forest: a geospatial approach. For Ecol Manage. 2011;262:1608-17.

68. Cavard X, Bergeron Y, Chen HYH, Paré D, Laganière J, Brassard B. Competition and facilitation between tree species change with stand development. Oikos. 2011;120:1683-95.

69. Binkley D. Mixtures of nitrogen-fixing and non-nitrogen-fixing tree species. In: Cannell MGR, Malcolm DC, Robertson PA, editors. The ecology of mixed species stands of trees. London: Blackwell Scientific; 1992. p. 99-123.

70. Kelty MJ. Comparative productivity of monocultures and mixedspecies stands. In: Kelty MJ, Larson BC, Oliver CD, editors. The ecology and silviculture of mixed-species forests. Dordrecht: Kluwer Academic Publishers; 1992. p. 125-41.

71. Bruelheide H, Nadrowski K, Assmann T, Bauhus J, Both S, Buscot F, et al. Designing forest biodiversity experiments: general considerations illustrated by a new large experiment in subtropical China. Methods Ecol Evol. 2014;5(1):74-89.

72. Baeten L, Verheyen K, Wirth C, Bruelheide H, Bussotti F, Finér L, et al. A novel comparative research platform designed to determine the functional significance of tree species diversity in European forests. Perspect Plant Ecol Evol Syst. 2013;15:281-91.

73. Verheyen K, Vanhellemont M, Auge H, Baeten L, Baraloto C, Barsoum $\mathrm{N}$ et al. Contributions of a global network of tree diversity experiments to sustainable forest plantations. Ambio. in press.

74. Sterba H, Rio M, Brunner A, Condes S. Effect of species proportion definition on the evaluation of growth in pure vs. mixed stands. Forest Syst. 2014;23(3):547-59.

75. Forrester DI, Schortemeyer M, Stock WD, Bauhus J, Khanna PK, Cowie AL. Assessing nitrogen fixation in mixed- and singlespecies plantations of Eucalyptus globulus and Acacia mearnsii. Tree Physiol. 2007;27:1319. doi:10.1093/treephys/27.9.1319.

76. Bouillet JP, Laclau JP, Goncalves JLM, Moreira MZ, Trivelin PCO, Jourdan C, et al. Mixed-species plantations of Acacia mangium and Eucalyptus grandis in Brazil 2: nitrogen accumulation in the stands and biological $\mathrm{N}_{2}$ fixation. For Ecol Manage. 2008;255:3918-30.

77. Hättenschwiler S, Tiunov AV, Scheu S. Biodiversity and litter decomposition in terrestrial ecosystems. Annu Rev Ecol Evol Syst. 2005;36:191-218.

78. Rothe A, Binkley D. Nutritional interactions in mixed species forests: a synthesis. Can J Forest Res. 2001;31(11):1855-70.

79. Gartner TB, Cardon ZG. Decomposition dynamics in mixedspecies leaf litter. Oikos. 2004;104:230-46.

80. Laclau J-P, Nouvellon Y, Reine C, Gonçalves JLM, Krushe AV, Jourdan C, et al. Mixing Eucalyptus and Acacia trees leads to fine root over-yielding and vertical segregation between species. Oecologia. 2013;172:903-13.

81. Jacob A, Hertel D, Leuschner C. On the significance of belowground overyielding in temperate mixed forests: separating species identity and species diversity effects. Oikos. 2013;122:46373.

82. Lang AC, Oheimb G, Scherer-Lorenzen M, Yang B, Trogisch S, Bruelheide $\mathrm{H}$, et al. Mixed afforestation of young subtropical trees 
promotes nitrogen acquisition and retention. J Appl Ecol. 2014;51:224-33.

83. Brassard BW, Chen HYH, Bergeron Y, Paré D. Differences in fine root productivity between mixed- and single-species stands. Funct Ecol. 2011;25:238-46.

84. Brassard BW, Chen HYH, Cavard X, Laganière J, Reich PB, Bergeron Y, et al. Tree species diversity increases fine root productivity through increased soil volume filling. J Ecol. 2013;101:210-9.

85. Valverde-Barrantes OJ, Smemo KA, Feinstein LM, Kershner MW, Blackwood CB. Aggregated and complementary: symmetric proliferation, overyielding, and mass effects explain fine-root biomass in soil patches in a diverse temperate deciduous forest landscape. New Phytol. 2015;205:731-42.

86. Binkley D, Valentine D. Fifty-year biogeochemical effects of green ash, white pine, and Norway spruce in a replicated experiment. For Ecol Manage. 1991;40(1-2):13-25.

87. Williams BL. Nitrogen dynamics in humus and soil beneath Sitka spruce (Picea sitchensis (Bong.) Carr.) planted in pure stands and in mixture with Scots pine (Pinus sylvestris L.). Plant and Soil. 1992;144:77-84.

88. Schwarz MT, Bischoff S, Blaser S, Boch S, Schmitt B, Thieme L, et al. More efficient aboveground nitrogen use in more diverse Central European forest canopies. For Ecol Manage. 2014;313: 274-82.

89. Neumann RB, Cardon ZG. The magnitude of hydraulic redistribution by plant roots: a review and synthesis of empirical and modeling studies. New Phytol. 2012;194:337-52.

90. Prieto I, Armas C, Pugnaire FI. Water release through plant roots: new insights into its consequences at the plant and ecosystem level. New Phytol. 2012;193:830-41.

91. Simard SW, Beiler KJ, Bingham MA, Deslippe JR, Philip LJ, Teste FP. Mycorrhizal networks: mechanisms, ecology and modelling. Fungal Biol Rev. 2012;26:39-60.

92. Schume H, Jost G, Hager H. Soil water depletion and recharge patterns in mixed and pure forest stands of European beech and Norway spruce. J Hydrol. 2004;289:258-74.

93. Schwendenmann L, Pendall E, Sanchez-Bragado R, Kunert N, Hölscher D. Tree water uptake in a tropical plantation varying in tree diversity: interspecific differences, seasonal shifts and complementarity. Ecohydrology. 2015;8:1-12.

94. André F, Jonard M, Ponette Q. Precipitation water storage capacity in a temperate mixed oak-beech canopy. Hydrol Processes. 2008;22:4130-41.

95. Augusto L, Schrijver AD, Vesterdal L, Smolander A, Prescott C, Ranger J. Influences of evergreen gymnosperm and deciduous angiosperm tree species on the functioning of temperate and boreal forests. Biol Rev. 2015;90:444-66.

96. Gebauer T, Horna V, Leuschner C. Canopy transpiration of pure and mixed forest stands with variable abundance of European beech. J Hydrol. 2012;442-443:2-14.

97. Ilek A, Kucza J, Szostek M. The effect of stand species composition on water storage capacity of the organic layers of forest soils. Eur J For Res. 2015;134:187-97.

98. Pretzsch H, Schütze G, Uhl E. Resistance of European tree species to drought stress in mixed versus pure forests: evidence of stress release by inter-specific facilitation. Plant Biol. 2013;15:483-95.

99. Roupsard O, Ferhi A, Granier A, Pallo F, Depommier D, Mallet B, et al. Reverse phenology and dry-season water uptake by Faidherbia albida (Del.) A. Chev. in an agroforestry parkland of Sudanese west Africa. Funct Ecol. 1999;13:460-72.

100. Saccone P, Delzon S, Pagès J-P, Brun J-J, Michalet R. The role of biotic interactions in altering tree seedling responses to an extreme climatic event. J Veg Sci. 2009;20:403-14.

101. Grossiord C, Granier A, Ratcliffe S, Bouriaud O, Bruelheide H, Chećko E, et al. Tree diversity does not always improve resistance of forest ecosystems to drought. Proc Natl Acad Sci. 2014;111(41):14812-5.

102. Forrester DI, Lancaster K, Collopy JJ, Warren CR, Tausz M. Photosynthetic capacity of Eucalyptus globulus is higher when grown in mixture with Acacia mearnsii. Trees Struct Funct. 2012;26:1203-13.

103. le Maire G, Nouvellon Y, Christina M, Ponzoni FJ, Gonçalves JLM, Bouillet J-P, et al. Tree and stand light use efficiencies over a full rotation of single- and mixed-species Eucalyptus grandis and Acacia mangium plantations. For Ecol Manage. 2013;288: 31-42.

104. Pollastrini M, Holland V, Brüggemann W, Koricheva J, Jussila I, Scherer-Lorenzen M, et al. Interactions and competition processes among tree species in young experimental mixed forests, assessed with chlorophyll fluorescence and leaf morphology. Plant Biol. 2014;16(2):323-31.

105. Pretzsch H. Canopy space filling and tree crown morphology in mixed-species stands compared with monocultures. For Ecol Manage. 2014;327:251-64.

106. Guisasola R, Tang X, Bauhus J, Forrester DI. Intra- and interspecific differences in crown architecture in Chinese subtropical mixed-species forests. For Ecol Manage. 2015;353:164-72.

107. Sapijanskas J, Paquette A, Potvin C, Kunert N, Loreau M. Tropical tree diversity enhances light capture through crown plasticity and spatial and temporal niche differences. Ecology. 2014;95:2479-92.

108. Jucker T, Bouriaud O, Coomes DA. Crown plasticity enables trees to optimize canopy packing in mixed-species forests. Funct Ecol. 2015;29:1078-86.

109. Bauhus J, van Winden AP, Nicotra AB. Above-ground interactions and productivity in mixed-species plantations of Acacia mearnsii and Eucalyptus globulus. Can J Forest Res. 2004;34: 686-94.

110. Lei X, Wang W, Peng C. Relationships between stand growth and structural diversity in spruce-dominated forests in New Brunswick, Canada. Can J Forest Res. 2009;39:1835-47. This study shows how structural diversity, in terms of diameter and height, can be correlated with forest growth.

111. Binkley D. Importance of size-density relationships in mixed stands of Douglas-fir and Red alder. For Ecol Manage. 1984;9: $81-5$.

112. Woodall CW, Miles PD, Vissage JS. Determining maximum stand density index in mixed species stands for strategic-scale stocking assessments. For Ecol Manage. 2005;216:367-77.

113. Loreau M, Hector A. Partitioning selection and complementarity in biodiversity experiments. Nature. 2001;412:72-6.

114. Cardinale BJ, Matulich KL, Hooper DU, Byrnes JE, Duffy E, Gamfeldt $\mathrm{L}$, et al. The functional role of producer diversity in ecosystems. Am J Bot. 2011;98:572-92.

115. Jactel H, Brockerhoff EG. Tree diversity reduces herbivory by forest insects. Ecol Lett. 2007;10:835-48.

116. Castegneyrol B, Jactel H, Vacher C, Brockerhoff EG, Koricheva J. Effects of plant phylogenetic diversity on herbivory depend on herbivore specialization. J Appl Ecol. 2014;51:134 41.

117. Hantsch L, Bien S, Radatz S, Braun U, Auge H, Bruelheide H. Tree diversity and the role of non-host neighbour tree species in reducing fungal pathogen infestation. J Ecol. 2014;102:1673-87.

118. Barbosa P, Hines J, Kaplan I, Martinson H, Szczepaniec A, Szendrei Z. Associational resistance and associational susceptibility: having right or wrong neighbors. Annu Rev Ecol Evol Syst. 2009; 40:1-20.

119. Jucker T, Bouriaud O, Avacaritei D, Coomes DA. Stabilizing effects of diversity on aboveground wood production in forest ecosystems: linking patterns and processes. Ecol Lett. 2014;17:1560-9.

120. Chisholm RA, Muller-Landau HC, Rahman KA, Bebber DP, Bin Y, Bohlman SA, et al. Scale-dependent relationships between tree 
species richness and ecosystem function in forests. $\mathrm{J}$ Ecol. 2013;101:1214-24.

121. Long JN, Dean TJ, Roberts SD. Linkages between silviculture and ecology: examination of several important conceptual models. For Ecol Manage. 2004;200:249-61.

122. Nguyen H, Herbohn J, Firn J, Lamb D. Biodiversity-productivity relationships in small-scale mixed-species plantations using native species in Leyte province, Philippines. Forest Ecol Manag. 2012;274:81-90.

123. Erskine PD, Lamb D, Bristow M. Tree species diversity and ecosystem function: can tropical multi-species plantations generate greater productivity? Forest Ecol Manag. 2006;233:205-10.

124. Potvin C, Mancilla L, Buchmann N, Monteza J, Moore T, Murphy $\mathrm{M}$, et al. An ecosystem approach to biodiversity effects: carbon pools in a tropical tree plantation. For Ecol Manage. 2011;261: 1614-24.

125. Caspersen JP, Pacala SW. Successional diversity and forest ecosystem function. Ecol Res. 2001;16:895-903.
126. Gamfeldt L, Snäll T, Bagchi R, Jonsson M, Gustafsson L, Kjellander P, et al. Higher levels of multiple ecosystem services are found in forests with more tree species. Nat Commun. 2013;4: 1340.

127. Grossiord C, Granier A, Gessler A, Pollastrini M, Bonal D. The influence of tree species mixture on ecosystem-level carbon accumulation and water use in a mixed boreal plantation. For Ecol Manage. 2013;298:82-92.

128. Shannon CE. A mathematical theory of communication. Bell Syst Techn J. 1948;27:379-423. 623-56.

129. Li Y, Härdtle W, Bruelheide H, Nadrowski K, Scholten T, Wehrden H, et al. Site and neighborhood effects on growth of tree saplings in subtropical plantations (China). For Ecol Manage. 2014;327:118-27.

130. Ruiz-Benito P, Gómez-Aparicio L, Paquette A, Messier C, Kattge J, Zavala MA. Diversity increases carbon storage and tree productivity in Spanish forests. Glob Ecol Biogeogr. 2014;23:311-22. 